\title{
$A{ }^{10}$ Be production-rate calibration for the Arctic
}

\author{
NICOLÁS E. YOUNG, ${ }^{1,2 *}$ JOERG M. SCHAEFER, ${ }^{1,3}$ JASON P. BRINER ${ }^{2}$ and BRENT M. GOEHRING ${ }^{4}$ \\ ${ }^{1}$ Lamont-Doherty Earth Observatory, Columbia University, Palisades, NY, 10964, USA \\ ${ }^{2}$ Department of Geology, University at Buffalo, Buffalo, NY, USA \\ ${ }^{3}$ Department of Earth and Environmental Sciences, Columbia University, New York, NY, USA \\ ${ }^{4}$ Department of Earth and Atmospheric Sciences, Purdue University, West Lafayette, IN, USA \\ Received 18 January 2013; Revised 16 April 2013; Accepted 18 April 2013
}

\begin{abstract}
We present a Baffin Bay ${ }^{10}$ Be production-rate calibration derived from glacial deposits in western Greenland and Baffin Island, and test our results against published ${ }^{10}$ Be calibration datasets to develop an Arctic ${ }^{10} \mathrm{Be}$ production rate. Our calibration comprises: (i) ${ }^{10} \mathrm{Be}$ measurements from moraine boulders linked to a ${ }^{14} \mathrm{C}$ dated moraine at Jakobshavn Isfjord in western Greenland, (ii) an independent and previously published ${ }^{10} \mathrm{Be}$ production rate at Jakobshavn Isfjord and (iii) re-measured ${ }^{10}$ Be concentrations from a Baffin Island calibration site that is included in the north-eastern North America dataset. Combined, we calculate a sea-level/high-latitude ${ }^{10} \mathrm{Be}$ production rate for the Baffin Bay region of $3.96 \pm 0.07$ atoms $\mathrm{g}^{-1} \mathrm{a}^{-1}$ (Lal/Stone scaling model). After testing the Baffin Bay rate against calibration sites in Norway and north-eastern North America, we calculate a more conservative Arctic production rate of $3.96 \pm 0.15$ atoms $\mathrm{g}^{-1} \mathrm{a}^{-1}$. The Baffin Bay and Arctic ${ }^{10}$ Be production rates are indistinguishable from the north-eastern North America ${ }^{10}$ Be production rate $\left(3.91 \pm 0.19\right.$ atoms g $\left.\mathrm{g}^{-1} \mathrm{a}^{-1}\right)$ and yield overall uncertainties of $<2-3.7 \%(1 \sigma)$. These production rates reduce systematic uncertainties in ${ }^{10} \mathrm{Be}-$ based chronologies of ice-margin change and allow ${ }^{10}$ Be-based chronologies to be more confidently compared with high-resolution climate records, such as those from Greenland ice cores. Copyright (C) 2013 John Wiley \& Sons, Ltd.
\end{abstract}

KEYWORDS: Arctic; Baffin Island; ${ }^{10}$ Be exposure dating; Greenland ice sheet; production rate.

\section{Introduction}

${ }^{10} \mathrm{Be}$ exposure dating is an invaluable tool for dating icemargin fluctuations in mountain-glacier and ice-sheet landscapes where organic remains for radiocarbon dating are often sparse or non-existent (Balco, 2011). Accordingly, ${ }^{10} \mathrm{Be}$ ages from glacial-geological features yield important insights into ocean-atmosphere-cryosphere teleconnections governing regional, hemispheric and global climate variability (e.g. Gosse et al., 1995; Ivy-Ochs et al., 1999; Stone et al., 2003; Briner et al., 2009; Schaefer et al., 2009; Licciardi et al., 2009; Young et al., 2012; Laabs et al., 2013). The accuracy and precision of these and future ${ }^{10} \mathrm{Be}$ chronologies, however, is critically dependent on knowledge of the ${ }^{10} \mathrm{Be}$ production rate.

The first ${ }^{10} \mathrm{Be}$ production-rate calibration dataset was derived from glacially eroded bedrock surfaces in the Sierra Nevada ( 2150-3560 m asl; Nishiizumi et al., 1989). Soon thereafter additional ${ }^{10} \mathrm{Be}$ calibration datasets were generated from moraines in Wyoming's Wind River Range ( $3200 \mathrm{~m}$; Gosse et al., 1995), Lake Bonneville shorelines ( 1500 m; Gosse and Klein, 1996), moraines deposited by the Laurentide Ice Sheet ( 300-375 m; Larsen, 1996), an Austrian landslide ( 1400-1700 m; Kubik et al., 1998; Kubik and IvyOchs, 2004), glacial deposits in Scotland ( $550 \mathrm{~m}$; Stone et al., 1998), and experimental water-target measurements ( $\sim 140$ and $3250 \mathrm{~m}$; Nishiizumi et al., 1996). These calibration datasets were combined to generate a 'global' ${ }^{10} \mathrm{Be}$ production rate of $\sim 4.6$ atoms $\mathrm{g}^{-1} \mathrm{a}^{-1}$ [07KNSTD; Stone (St) scaling; 10-13\% uncertainties; Gosse and Phillips, 2001]. The global ${ }^{10} \mathrm{Be}$ production rate was updated by Balco et al. (2008), which added ${ }^{10}$ Be measurements from Peru ( 4045 $\mathrm{m}$; Farber et al., 2005), to yield a ${ }^{10} \mathrm{Be}$ production rate of $4.47 \pm 0.40$ atoms $\mathrm{g}^{-1} \mathrm{a}^{-1}$ (St).

Building upon these pioneering studies are recent ${ }^{10} \mathrm{Be}$ calibration experiments from north-eastern North America

${ }^{*}$ Correspondence: N. E. Young, ${ }^{1}$ Lamont-Doherty Earth Observatory, as above. E-mail: nicolasy@Ideo.columbia.edu
(NENA; Balco et al., 2009), New Zealand (Putnam et al., 2010a), Patagonia (Kaplan et al., 2011), Norway (Fenton et al., 2011; Goehring et al., 2012) and Greenland (Briner et al., 2012). These second-generation ${ }^{10} \mathrm{Be}$ production rates are distinct from the previously published canonical global ${ }^{10} \mathrm{Be}$ production rate in two key aspects: (i) they are systematically $\sim 7-14 \%$ lower, and (ii) they have lower uncertainties ( $<5$ vs. $\sim 10 \%)$. Thus, ${ }^{10}$ Be ages calculated using the latest production rates are systematically older and more precise (assuming the same ${ }^{10} \mathrm{Be}$ measurement precision) than ${ }^{10} \mathrm{Be}$ ages calculated with the global production rate. In the Southern Hemisphere, for example, ${ }^{10} \mathrm{Be}$ ages calculated with the New Zealand rate have resulted in robust submillennial-scale records of glacier change (e.g. Kaplan et al., 2011; Putnam et al., 2010b, 2012) that reinforce the demand for additional high-precision ${ }^{10} \mathrm{Be}$ production-rate calibration experiments in other regions.

Rapid and ongoing changes within the Arctic cryosphere can be better understood through ${ }^{10} \mathrm{Be}$-based reconstructions of ice-sheet and glacier change that yield important insights into the sensitivity of ice masses to different forcing mechanisms. To maximize the potential of this approach, however, well-constrained ${ }^{10} \mathrm{Be}$ production-rate calibrations must be developed in the Arctic to generate ice-margin reconstructions that can be easily compared with high-resolution climate archives. Moreover, suitable Arctic ${ }^{10} \mathrm{Be}$ calibration sites can be used to calculate sea-level high-latitude (SLHL) production rates from SLHL locations. In contrast, ${ }^{10} \mathrm{Be}$ calibration datasets located at high altitude and mid to low latitudes (see examples above) must be scaled to reflect ${ }^{10} \mathrm{Be}$ production at SLHL, which may incorporate altitudinal and latitudinal scaling errors into the reference ${ }^{10} \mathrm{Be}$ production rates calculated at these locations. Thus, developing reference ${ }^{10} \mathrm{Be}$ production rates at Arctic locales can minimize any potential uncertainty in the production rate contributed by altitudinal and latitudinal scaling errors.

We present a new regional ${ }^{10}$ Be production-rate calibration dataset with $<2 \%$ precision $(1 \sigma)$ from low-altitude $(\sim 65-350$ 
$\mathrm{m}$ asl) ${ }^{14} \mathrm{C}$-dated glacial features located on opposing sides of Baffin Bay in western Greenland and east-central Baffin Island $\left(\sim 69-70^{\circ} \mathrm{N}\right.$; Fig. 1). We test these data against existing ${ }^{10} \mathrm{Be}$ production-rate calibration datasets in Norway and NENA to calculate an Arctic ${ }^{10}$ Be production rate.

\section{Baffin Bay ${ }^{10}$ Be production-rate calibration sites}

\section{Jakobshavn Isfjord, western Greenland: the Marrait and Tasiussaq moraines}

Extensive work in the Jakobshavn Isfjord region over several decades has produced a well-constrained history of the icesheet margin between ca. 10 and 7 ka (Weidick, 1968; Long et al., 2006; Weidick and Bennike, 2007; Briner et al., 2010; Corbett et al., 2011; Young et al., 2011a, b, 2013). Here we briefly highlight the Fjord Stade moraine system (Fig. 1), comprising the older Marrait and younger Tasiussaq moraines, and their ${ }^{14} \mathrm{C}$-based depositional ages that are later combined with ${ }^{10} \mathrm{Be}$ measurements from Marrait and Tasiussaq moraine boulders to develop site-specific ${ }^{10} \mathrm{Be}$ production-rate calibration datasets.

Following retreat of the Greenland Ice Sheet out of Disko Bugt ca. $10 \mathrm{ka}$, the Marrait moraine at Jakobshavn Isfjord was deposited $9175 \pm 45 \mathrm{cal}$ a BP (Young et al., 2011b). This age is derived from bracketing ${ }^{14} \mathrm{C}$ ages on a minerogenic sediment unit deposited in Pluto Lake during emplacement of the Marrait moraine (Fig. 1). Pluto Lake is a threshold lake (e.g. Kaplan et al., 2002; Briner et al., 2010) currently dominated by organic-rich sedimentation; however, during emplacement of the Marrait moraine, Jakobshavn Isbræ spilt silt-laden meltwater into Pluto Lake leading to a thick minerogenic unit bounded by fossiliferous gyttja (Figs 1B and 2A; Young et al., 2011b). Thus, bracketing ${ }^{14} \mathrm{C}$ ages from sharp organic-minerogenic contacts above and below the minerogenic unit constrain the timing of Marrait moraine formation (Fig. 2; Supporting Information Table S1). Two maximum-limiting ${ }^{14} \mathrm{C}$ ages immediately below the minerogenic unit are $9190 \pm 60$ and $9110 \pm 80 \mathrm{cal}$ a BP $(1 \sigma)$ and two minimum-limiting ${ }^{14} \mathrm{C}$ ages directly above the minerogenic unit are $9210 \pm 70$ and $9190 \pm 60$ cal a BP. All maximum- and minimum-constraining ${ }^{14} \mathrm{C}$ ages overlap at $1 \sigma$ and we calculate a mean age of $9175 \pm 45 \mathrm{cal}$ a BP for deposition of the sediment unit, and thus the Marrait moraine (Young et al., 2011b). In addition, of the three Baffin Bay calibration datasets presented here, only the Marrait moraine ${ }^{14} \mathrm{C}$ chronology does not include ${ }^{14} \mathrm{C}$ ages from marine fauna, which may be affected by uncertainties in the applied marine reservoir corrections.

The age of the Tasiussaq moraine is constrained by several maximum- and minimum-limiting ${ }^{14} \mathrm{C}$ ages in the Jakobshavn Isfjord region (Long et al., 2006; Weidick and Bennike, 2007). Maximum-constraining ${ }^{14} \mathrm{C}$ ages of $8800 \pm$ $340,8750 \pm 220,8670 \pm 260$ and $8570 \pm 400 \mathrm{cal}$ a BP are from marine bivalves overlain by Tasiussaq outwash south of the Isfjord (see Weidick and Bennike, 2007; Briner et al., 2012). All maximum-constraining ages use the standard


Figure 1. Locations of Jakobshavn Isfjord (JI) and Clyde Inlet (CI) in the Baffin Bay (BB) region. (A) Marrait and Tasiussaq moraines at Jakobshavn Isfjord, and the locations of Pluto Lake south of the Isfjord and the sampled boulders from the Marrait moraine north of the Isfjord. (B) The Marrait moraine (red dots) resting directly adjacent to Pluto Lake. Pluto Lake's long axis is $\sim 500 \mathrm{~m}$. (C) Boulder-rich segment of the Marrait moraine north of the Isfjord. This figure is available in colour online at wileyonlinelibrary.com. 

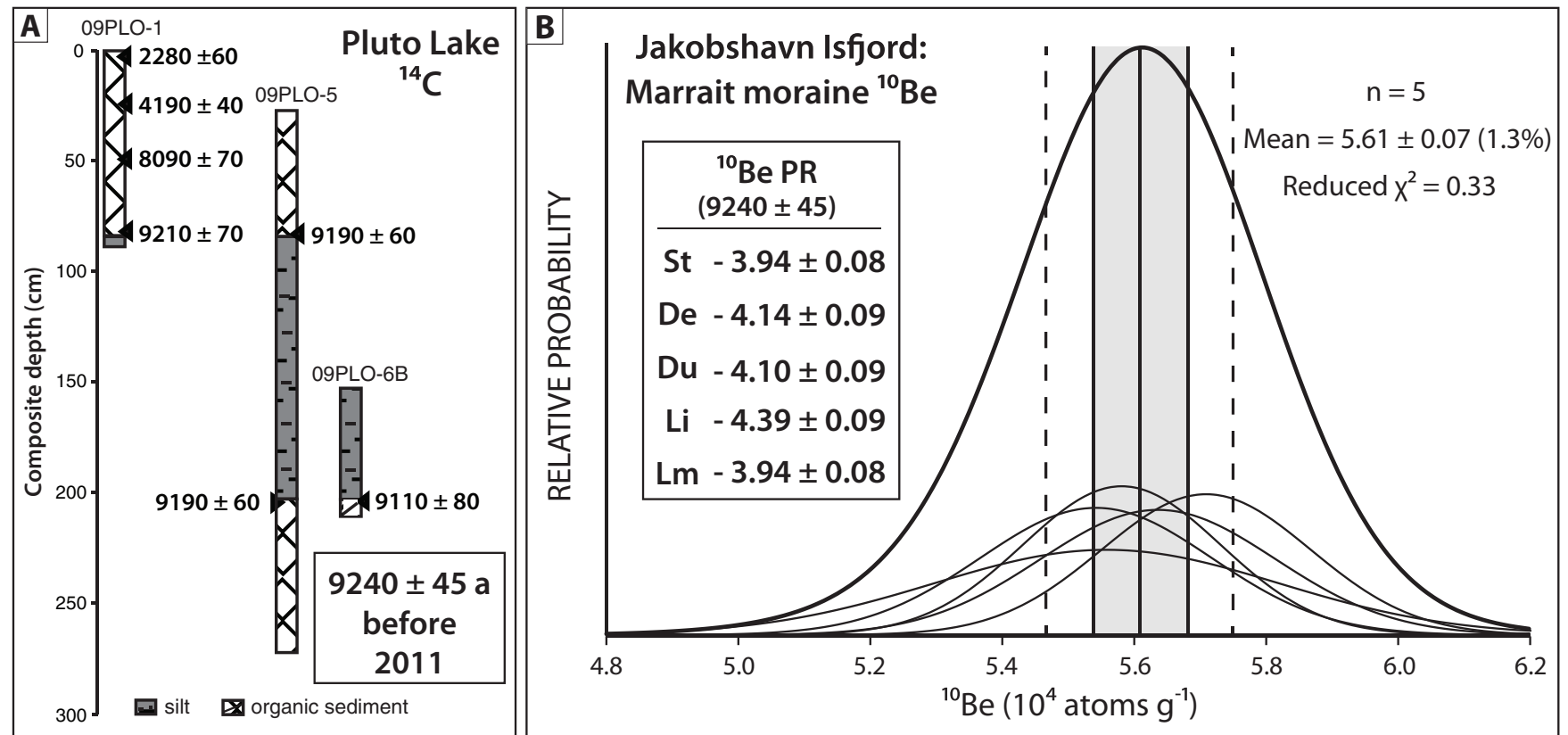

Figure 2. (A) Sediment stratigraphy from Pluto Lake with ${ }^{14} \mathrm{C}$ sample locations. The alternating units of organic- and minerogenic-rich sediments show sharp transitions. The thick minerogenic section was deposited during emplacement of the Marrait moraine $9175 \pm 45$ cal a $\mathrm{BP}$ or $9240 \pm$ 45 a before $\mathrm{CE} 2011$. (B) Normal kernel density estimate of ${ }^{10} \mathrm{Be}$ concentrations from boulders resting on the Marrait moraine. Inset is the ${ }^{10} \mathrm{Be}$ reference production rate (atoms $\mathrm{g}^{-1} \mathrm{a}^{-1}$ ) using only the Marrait moraine dataset.

marine reservoir correction $(410$ a; $\Delta R=0$ a), which is the typical value used in western Greenland (e.g. Lloyd et al., 2005; Weidick and Bennike, 2007). Minimum-constraining ${ }^{14} \mathrm{C}$ ages of $7740 \pm 80,7660 \pm 40,7600 \pm 80$ and $7590 \pm 80 \mathrm{cal} \mathrm{a}$ BP are from basal lake sediments located inboard of the Tasiussaq moraine (Long et al., 2006). Combined, maximum- and minimum-constraining ${ }^{14} \mathrm{C}$ ages indicate that the Tasiussaq moraine was deposited between 8700 \pm 100 and $7650 \pm 70 \mathrm{cal}$ a BP (Briner et al., 2012; Young et al., 2013).

\section{Clyde Inlet, Baffin Island}

At the head of Clyde Inlet rests a prominent ice-contact glaciomarine delta whose depositional age is constrained by bracketing ${ }^{14} \mathrm{C}$ ages (Briner et al., 2007). Resting on the delta surface are imbricated clast-supported boulders, and draped onto the foreslope of the delta are bivalve-rich marine muds. Because the delta must have been emplaced before the draped marine deposits, ${ }^{14} \mathrm{C}$ ages from bivalves provide minimum age constrains for the delta. Three ${ }^{14} \mathrm{C}$ ages from these deposits are $7950 \pm 45,7905 \pm 70$ and $7790 \pm 55 \mathrm{cal} \mathrm{a}$ BP (recalibrated from Briner et al., 2007; locally calibrated $\Delta R=130$ a). These ages are in stratigraphic order and therefore the lowermost (oldest) age is the closest constraining minimum age for the delta $(7950 \pm 45$ cal a BP). The maximum age of the delta is constrained by a ${ }^{14} \mathrm{C}$ age of $8435 \pm 50$ cal a BP from an older, higher elevation icecontact delta located $\sim 4 \mathrm{~km}$ down-fjord (Briner et al., 2007). Thus, our target delta at the head of Clyde Inlet, including the boulders resting atop the delta, was deposited between 8435 \pm 50 and $7950 \pm 45 \mathrm{cal}$ a BP.

\section{Materials and methods}

\section{${ }^{10}$ Be sample collection}

We sampled five boulders on the Marrait moraine at a location $\sim 10 \mathrm{~km}$ north of Jakobshavn Isfjord (Figs 1 and 3) because there are no boulders suitable for ${ }^{10} \mathrm{Be}$ dating on the segment of the Marrait moraine located directly adjacent to Pluto Lake (Fig. 1B). In fact, several field seasons in the Jakobshavn Isfjord region revealed that the sampled Marrait moraine segment at Jakobshavn Isfjord is the only section of this moraine with boulders suitable for ${ }^{10} \mathrm{Be}$ dating. Boulders were sampled with a hammer and chisel, and we sampled flat surfaces avoiding boulder edges. Shielding by the surrounding topography was measured with a clinometer, and sample elevations were measured with a handheld GPS receiver with a vertical uncertainty of $\sim 5 \mathrm{~m}$. These sampling protocols were used for Tasiussaq moraine boulders $(n=6)$, which were sampled in 2008-2009 (Young et al., 2011b), and boulders resting atop the ice-contact delta at Clyde Inlet sampled in 2001-2003 ( $n=7$; Briner et al., 2007).

\section{${ }^{10}$ Be sample preparation and ${ }^{10}$ Be data}

Chemical processing for samples from the Marrait moraine took place at the University of Buffalo Cosmogenic Nuclide Laboratory following procedures modified from Kohl and Nishiizumi (1992) and the University of Vermont Cosmogenic Laboratory's beryllium extraction procedures (www.uvm.edu/ cosmolab). Samples from Clyde Inlet were prepared at the Lamont-Doherty Earth Observatory Cosmogenic Nuclide Laboratory following standard Be extraction methods (www. Ideo.columbia.edu/tcn/). All ${ }^{10} \mathrm{Be} /{ }^{9} \mathrm{Be}$ ratios were measured at the Lawrence Livermore National Laboratory Center for Accelerator Mass Spectrometry relative to the 07KNSTD standard with a reported ratio of $2.85 \times 10^{-12}$ (Nishiizumi et al., 2007; Rood et al., 2010) and corrected for background procedural blanks (Table 1).

All sample information and measured ${ }^{10} \mathrm{Be}$ concentrations can be found in Table $1 .{ }^{10}$ Be concentrations from Marrait moraine boulders exhibit analytical errors ranging from 1.9 to $3.4 \%$ and all ${ }^{10} \mathrm{Be}$ concentrations overlap at $1 \sigma$ (Fig. 2). Measured ${ }^{10} \mathrm{Be}$ concentrations from Tasiussaq moraine boulders are reported in Young et al. (2011b, 2013), but are also included in Table 1 for reference. ${ }^{10} \mathrm{Be}$ concentrations from 

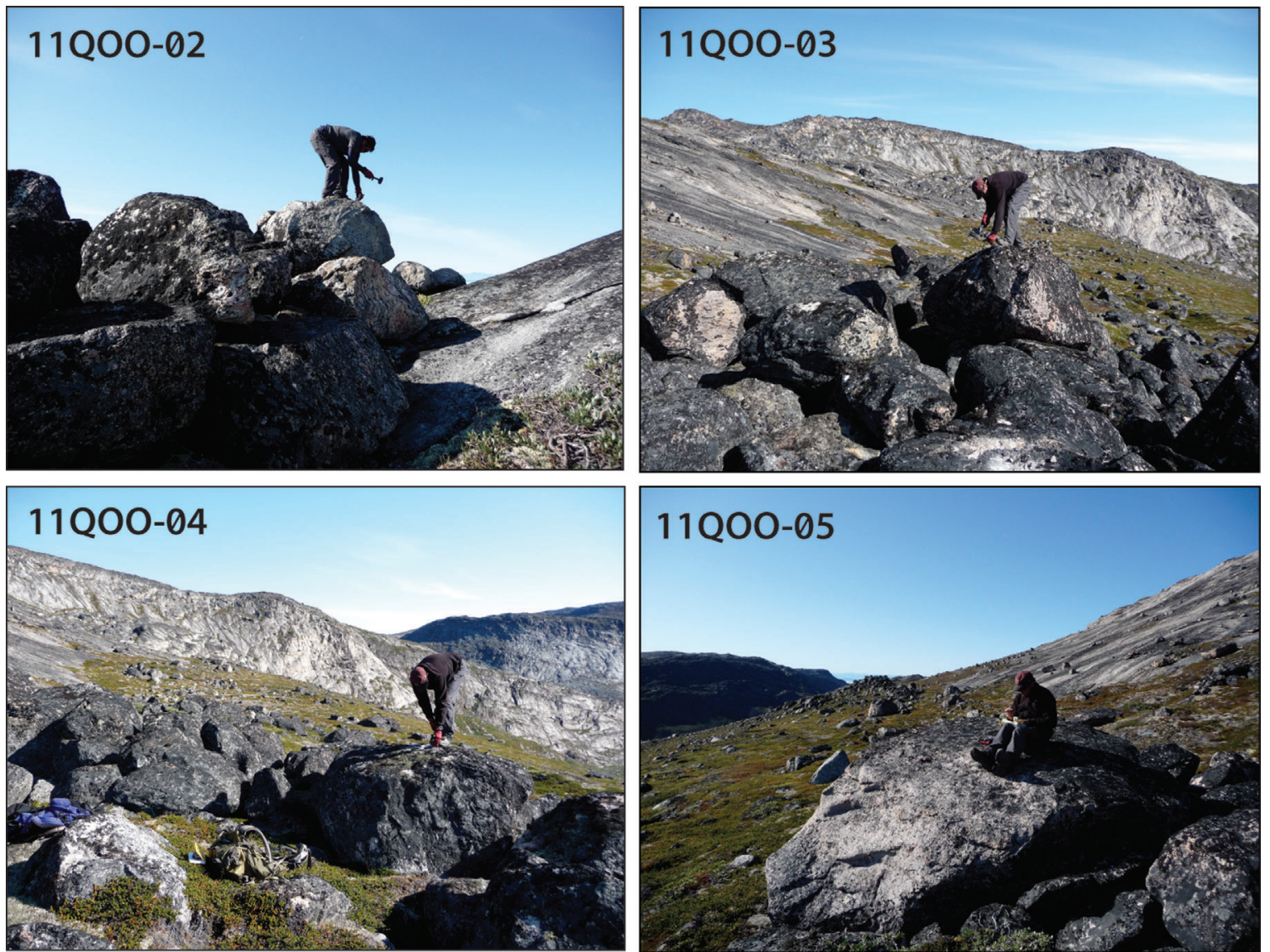

Figure 3. Examples of sampled boulders from the Marrait moraine north of Jakobshavn Isfjord. In each photo, the person is standing on top of the sampled boulder used in the production-rate calibration. This figure is available in colour online at wileyonlinelibrary.com.

Tasiussaq moraine boulders have analytical errors ranging between 1.7 and $2.5 \%$.

${ }^{10} \mathrm{Be}$ measurements from boulders resting atop the icecontact delta at Clyde Inlet were originally completed between 2001 and 2003 and included as part of the NENA ${ }^{10}$ Be production-rate calibration dataset (Briner et al., 2007; Balco et al., 2009; Table 1; Fig. 4). We re-measured these samples and obtained analytical uncertainties ranging between 2.0 and $2.7 \%$ with ${ }^{10}$ Be concentrations overlapping at $1 \sigma$ (Table 1 ). In addition, the re-measured ${ }^{10} \mathrm{Be}$ concentrations overlap with measurements completed in 2001-2003 (Fig. 4). The ${ }^{10} \mathrm{Be}$ production-rate calibration values for the Clyde Inlet dataset presented here are based exclusively on the 2012 re-measurements.

\section{Production-rate calculations}

To calculate site-specific production rates and their uncertainties for the Baffin Bay datasets, we use a $\chi^{2}$ minimization by selecting the best-fitting ${ }^{10} \mathrm{Be}$ production rate that minimizes the misfit between the calculated ${ }^{10} \mathrm{Be}$ concentration and the measured ${ }^{10} \mathrm{Be}$ concentration. At sites where the independent age control is limited by maximum- and minimum-limiting radiocarbon ages (Clyde River, Tasiussaq moraine), we calculate reference production rates at each end member and then take the midpoint of these values to estimate the reference production rate. Site-specific production rates are then used to calculate a Baffin Bay production rate using the error-weighted mean of these values (see discussion below). To develop a broader Arctic production rate, we use a $\chi^{2}$ minimization by selecting the best-fitting ${ }^{10} \mathrm{Be}$ production rate that minimizes the misfit between predicted ${ }^{10} \mathrm{Be}$ ages and the true age of the geomorphic feature at the Baffin Bay calibration sites. This approach avoids the practice of estimating minimum and maximum bounding ages by a single probability distribution (Clyde River, Tasiussaq moraine), and instead imposes a penalty to the fit only if the predicted ${ }^{10} \mathrm{Be}$ ages lie outside of the bounding age constraints. The bestfitting Baffin Bay production rate with this method is used to calculate predicted ${ }^{10} \mathrm{Be}$ ages at additional ${ }^{10} \mathrm{Be}$ calibration sites (Norway, Connecticut River Valley), and the misfit between predicted and true ages at these calibration sites is used to estimate an Arctic production rate uncertainty. These calibration sites are included in our analysis because they rest at similar altitudes as the Baffin Bay sites $(<400 \mathrm{~m}$ asl), and they are located at latitudes where the geomagnetic cutoff rigidities are similar to those for the Baffin Bay sites $(\sim 5-<2$ GV; Lifton et al., 2008). We note that the two methods described here yield the same baseline production rate values; however, the production rate uncertainty differs between methods, which are discussed in detail below.

$\mathrm{SLHL}{ }^{10} \mathrm{Be}$ production rates were determined using the five common scaling schemes (Lal, 1991; Stone, 2000; Dunai, 2001; Lifton et al., 2005; Desilets et al., 2006). ${ }^{10} \mathrm{Be}$ concentrations were calculated using Matlab code developed for the CRONUS-Earth web-based calculator, version 2.2 (Balco et al., 2008). Air pressure changes with elevation are calculated following the standard atmosphere equation, with sea level air pressure and temperature derived from the NCAR/NCEP reanalysis data product (www.cdc.noaa.gov/ ncep_reanalysis/). Production of ${ }^{10} \mathrm{Be}$ by muons is absolutely determined following Heisinger et al. (2002a, b); therefore production rates are reported for spallation only. In the text we present and discuss ${ }^{10} \mathrm{Be}$ production rates using the 


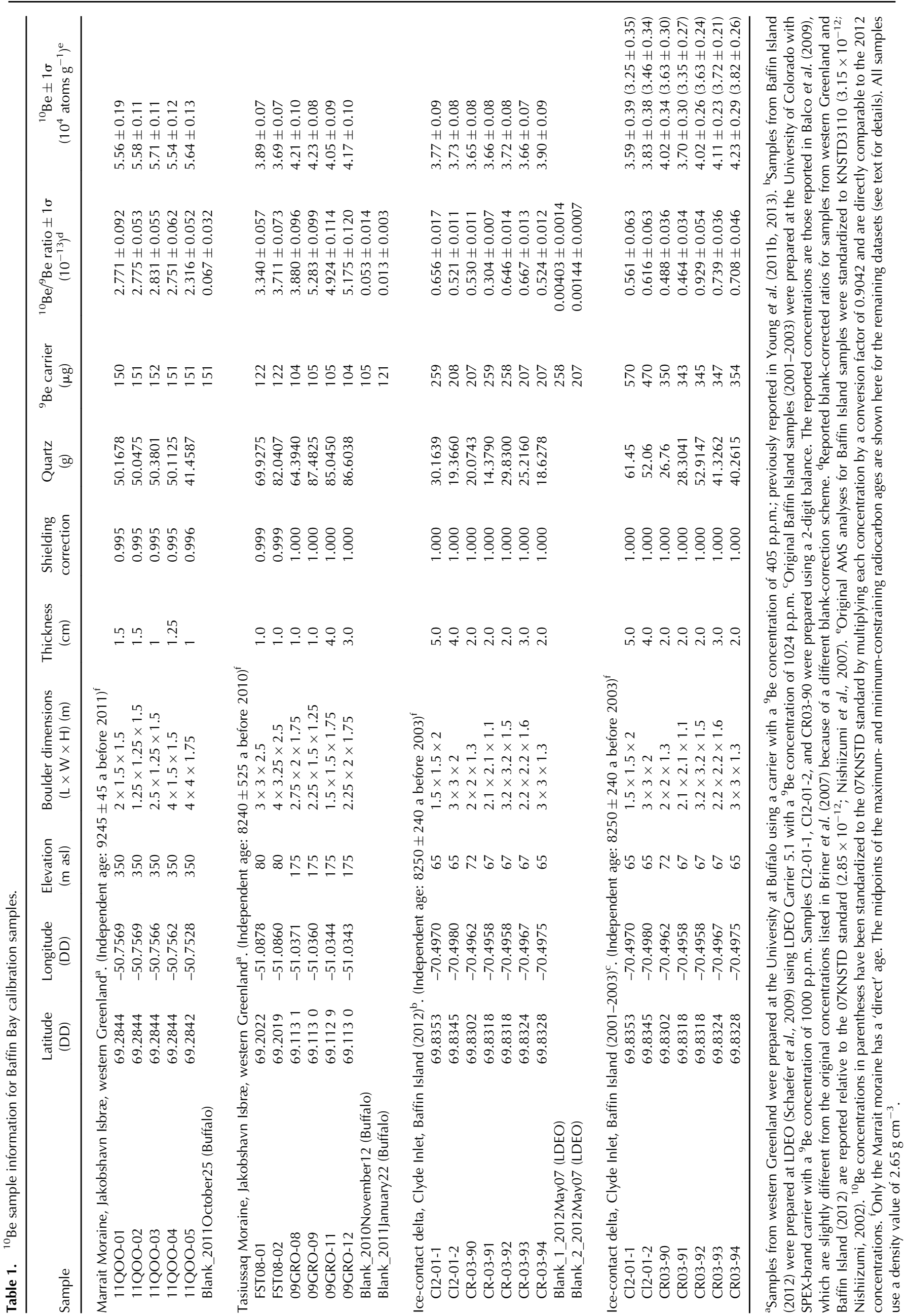


common 'St' scaling scheme, but production rates based on alternative scaling schemes are provided in Tables 2 and 3.

${ }^{10} \mathrm{Be}$ production occurs until the year of sample collection, whereas ${ }^{14} \mathrm{C}$ ages are reported relative to the year $1950 \mathrm{AD}$. To synchronize the ${ }^{10} \mathrm{Be}$ and ${ }^{14} \mathrm{C}$ time scales, we added 61 years (CE2011) to the calibrated ${ }^{14} \mathrm{C}$ age of the Marrait moraine, 60 years (CE2010) to the calibrated ${ }^{14} \mathrm{C}$ ages that bracket deposition of the Tasiussaq moraine and 53 years (CE2001-2003) to the calibrated ${ }^{14} \mathrm{C}$ ages that constrain deposition of the Clyde Inlet ice-contact delta; ages were then rounded to the nearest decade. Aligning the ${ }^{10} \mathrm{Be}$ and ${ }^{14} \mathrm{C}$ time scales for the Tasiussaq moraine dataset results in a slightly lower production rate than the value reported in Briner et al. (2012). We assume zero erosion for all boulder surfaces because boulders displayed no discernible grain-tograin relief and striations were commonly observed on several boulders (Young et al., 2011a, b, 2013). In addition, we do not correct ${ }^{10} \mathrm{Be}$ concentrations for snow cover. All boulder locations are from open, windswept locations, and at Clyde Inlet, snow-free boulders on the ice-contact delta were sampled in the spring - the season of maximum snow cover.

\section{${ }^{10}$ Be production-rate calibrations}

\section{Baffin Bay}

The local ${ }^{10}$ Be production rates for the Marrait, Tasiussaq and Clyde Inlet datasets are $6.07 \pm 0.08,5.08 \pm 0.32$ and $4.52 \pm$
0.13 atoms $\mathrm{g}^{-1} \mathrm{a}^{-1}$, respectively. To compare calibration experiments from different locations, however, local production rates must be referenced to SLHL; the reference ${ }^{10} \mathrm{Be}$ production rates below are calculated using the misfit between calculated and measured ${ }^{10} \mathrm{Be}$ concentrations (see above).

The reference ${ }^{10} \mathrm{Be}$ production rate at Jakobshavn Isfjord based solely on the Marrait moraine ${ }^{10} \mathrm{Be}$ and ${ }^{14} \mathrm{C}$ dataset is $3.94 \pm 0.08$ atoms $\mathrm{g}^{-1} \mathrm{a}^{-1}$ (St; Table 2). Supporting this ${ }^{10} \mathrm{Be}$ production rate are minimum and maximum allowable ${ }^{10} \mathrm{Be}$ production rates from Jakobshavn Isfjord of 3.67 and 4.19 atoms $\mathrm{g}^{-1} \mathrm{a}^{-1}$ with a mid-point value of $3.93 \pm 0.26$ atoms $\mathrm{g}^{-1} \mathrm{a}^{-1}$ (Fig. 4; Briner et al., 2012). These values utilize maximum- and minimum-constraining ${ }^{14} \mathrm{C}$ ages on the Tasiussaq moraine and ${ }^{10} \mathrm{Be}$ concentrations from Tasiussaq moraine boulders (Table 1; Young et al., 2011b; Briner et al., 2012). At Clyde Inlet, the minimum and maximum allowable reference ${ }^{10} \mathrm{Be}$ production rates based on bracketing ${ }^{14} \mathrm{C}$ ages are 3.89 and 4.14 atoms $\mathrm{g}^{-1} \mathrm{a}^{-1}$ with a midpoint value of $4.02 \pm 0.13$ atoms $g^{-1} \mathrm{a}^{-1}$ (Table 2; Fig. 4). In summary, the three independent reference ${ }^{10} \mathrm{Be}$ production rate values from the Marrait, Tasiussaq and Clyde Inlet datasets are $3.94 \pm 0.08,3.93 \pm 0.26$ and $4.02 \pm 0.13$ atoms $\mathrm{g}^{-1} \mathrm{a}^{-1}$, respectively.

The ${ }^{10} \mathrm{Be}$ production-rate calibration values from the Marrait, Tasiussaq and Clyde Inlet calibration datasets display high internal consistency as they are statistically identical values. The arithmetic mean and standard deviation of these
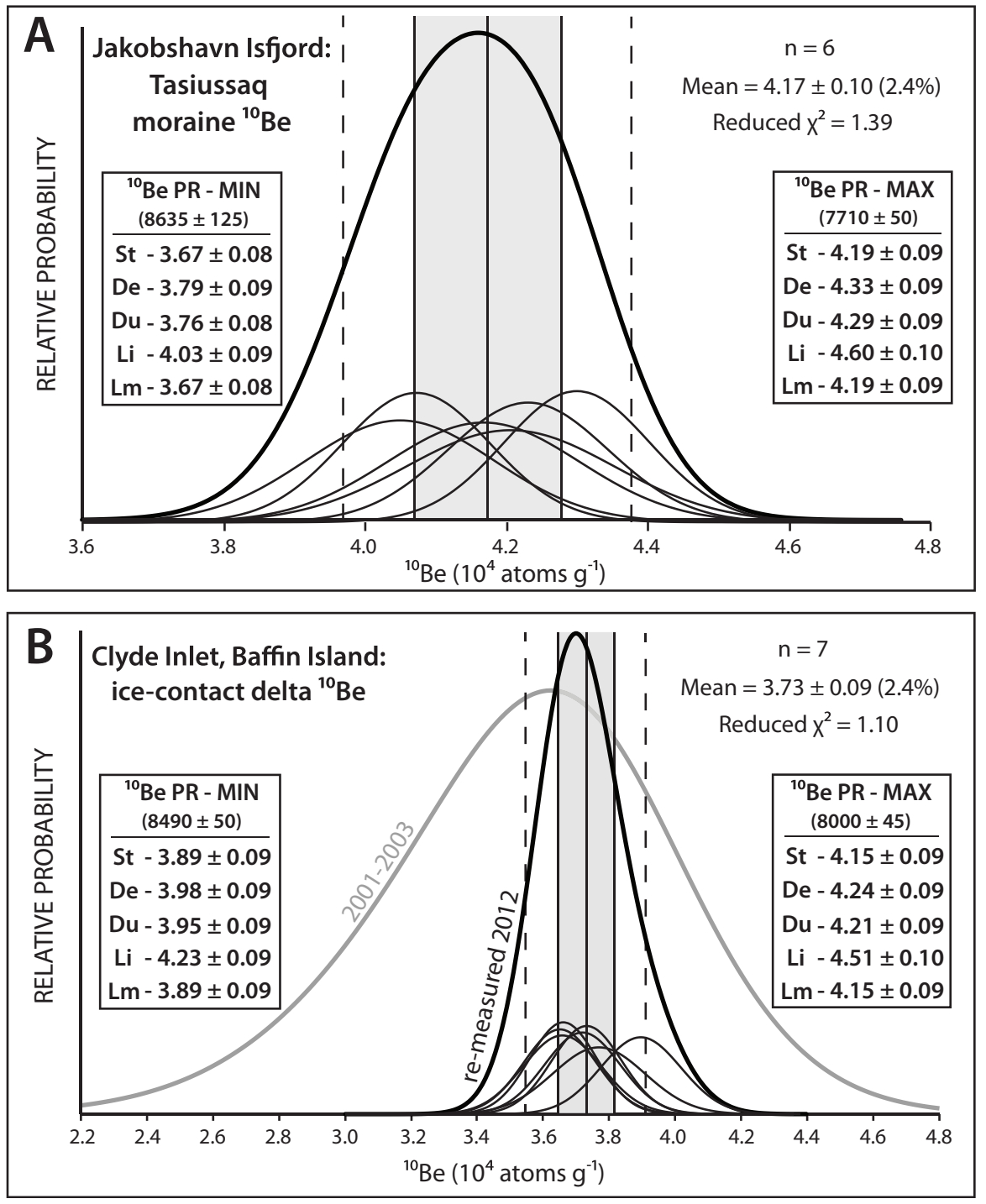

Figure 4. (A) Normal kernel density estimate of ${ }^{10} \mathrm{Be}$ concentrations from boulders resting on the Tasiussaq moraine, and the maximum and minimum allowable reference ${ }^{10} \mathrm{Be}$ production rates (atoms g ${ }^{-1} \mathrm{a}^{-1}$ ) based on the independent ${ }^{14} \mathrm{C}$ control. ${ }^{10} \mathrm{Be}$ concentrations have been scaled to reflect the 95- $\mathrm{m}$ altitude difference between boulder elevations on opposing sides of the Isfjord (Table 1). (B) Two generations of ${ }^{10} \mathrm{Be}$ concentrations from boulders resting on the ice-contact delta at Clyde Inlet, Baffin Island. The summed probability of the original ${ }^{10} \mathrm{Be}$ concentrations (2001-2003) are shown in gray; individual measurements (not shown) had $1 \sigma$ analytical uncertainties ranging from 5.6 to $10.9 \%$ (Briner et al., 2007; Balco et al., 2009). New ${ }^{10} \mathrm{Be}$ concentrations (remeasured 2012) with $1 \sigma$ analytical uncertainties ranging from 2.0 to $2.7 \%$ are in black. The maximum and minimum allowable reference ${ }^{10} \mathrm{Be}$ production rates based on the independent ${ }^{14} \mathrm{C}$ control for the icecontact delta use these new measurements. 
Table 2a. Baffin Bay ${ }^{10}$ Be production-rate calibration datasets.

\begin{tabular}{|c|c|c|c|c|c|}
\hline $\begin{array}{l}\text { Scaling } \\
\text { scheme ID }\end{array}$ & $\begin{array}{l}\text { Marrait Moraine } \\
\text { (this study) }\end{array}$ & $\begin{array}{l}\text { Tasiussaq } \\
\text { Moraine }\end{array}$ & $\begin{array}{l}\text { Clyde inlet, } \\
\text { Baffin Island }\end{array}$ & $\begin{array}{c}\text { Baffin Bay } \\
(\text { mean } \pm 1 \text { SD })\end{array}$ & $\begin{array}{c}\text { Baffin Bay } \\
\text { (error-weighted mean) }\end{array}$ \\
\hline St & $3.94 \pm 0.08(2.0 \%)$ & $3.93 \pm 0.26(6.6 \%)$ & $4.02 \pm 0.13(3.2 \%)$ & $3.96 \pm 0.05(1.3 \%)$ & $3.96 \pm 0.07(1.8 \%)$ \\
\hline De & $4.14 \pm 0.09(2.2 \%)$ & $4.06 \pm 0.27(6.7 \%)$ & $4.11 \pm 0.13(3.2 \%)$ & $4.10 \pm 0.04(1.0 \%)$ & $4.13 \pm 0.07(1.7 \%)$ \\
\hline Du & $4.10 \pm 0.09(2.2 \%)$ & $4.03 \pm 0.27(6.7 \%)$ & $4.08 \pm 0.13(3.2 \%)$ & $4.07 \pm 0.04(1.0 \%)$ & $4.09 \pm 0.07(1.7 \%)$ \\
\hline $\mathrm{Li}$ & $4.39 \pm 0.09(2.1 \%)$ & $4.32 \pm 0.29(6.9 \%)$ & $4.37 \pm 0.14(3.2 \%)$ & $4.36 \pm 0.04(1.0 \%)$ & $4.38 \pm 0.07(1.6 \%)$ \\
\hline $\mathrm{Lm}$ & $3.94 \pm 0.08(2.0 \%)$ & $3.93 \pm 0.26(6.6 \%)$ & $4.02 \pm 0.13(3.2 \%)$ & $3.96 \pm 0.05(1.3 \%)$ & $3.96 \pm 0.07(1.8 \%)$ \\
\hline
\end{tabular}

Table 2b. Arctic ${ }^{10}$ Be production-rate calibration datasets.

\begin{tabular}{lcccccc}
\hline Scaling & Baffin Bay & Norway-Oldedalen & Norway-Halsnøy & Norway-Grøtlandsura & Norway-Russenes & CT River Valley \\
\hline St & $3.96 \pm 0.07(1.8 \%)$ & $4.04 \pm 0.13(3.2 \%)$ & $4.19 \pm 0.11(2.6 \%)$ & $3.63 \pm 0.15(4.1 \%)$ & $4.03 \pm 0.21(5.0 \%)$ & $3.98 \pm 0.13(3.3 \%)$ \\
De & $4.13 \pm 0.07(1.7 \%)$ & $4.17 \pm 0.13(3.1 \%)$ & $4.29 \pm 0.11(2.6 \%)$ & $3.72 \pm 0.15(4.0 \%)$ & $4.15 \pm 0.21(5.1 \%)$ & $4.21 \pm 0.14(3.3 \%)$ \\
Du & $4.09 \pm 0.07(1.7 \%)$ & $4.16 \pm 0.13(3.1 \%)$ & $4.29 \pm 0.11(2.6 \%)$ & $3.69 \pm 0.15(4.1 \%)$ & $4.11 \pm 0.21(5.1 \%)$ & $4.24 \pm 0.14(3.3 \%)$ \\
Li & $4.38 \pm 0.07(1.6 \%)$ & $4.44 \pm 0.14(3.2 \%)$ & $4.58 \pm 0.12(2.6 \%)$ & $3.98 \pm 0.16(4.0 \%)$ & $4.43 \pm 0.22(5.0 \%)$ & $4.60 \pm 0.15(3.3 \%)$ \\
Lm & $3.96 \pm 0.07(1.8 \%)$ & $4.04 \pm 0.13(3.2 \%)$ & $4.19 \pm 0.11(2.6 \%)$ & $3.63 \pm 0.15(4.1 \%)$ & $4.04 \pm 0.20(5.0 \%)$ & $3.92 \pm 0.13(3.3 \%)$ \\
\hline
\end{tabular}

Values in parentheses are $1 \sigma$ uncertainties. Oldedalen-production rate using only the ${ }^{10}$ Be dataset from Oldedalen (Goehring et al., 2012). Halsnøy-production rate using only the ${ }^{10}$ Be dataset and no uplift correction from Halsnøy (Goehring et al., 2012). Norway-Grøtlandsuraproduction rate using only the ${ }^{10} \mathrm{Be}$ dataset from Grøtlandsura (Fenton et al., 2011). Norway-Russenes-production rate using only the ${ }^{10} \mathrm{Be}$ dataset from Russenes (Fenton et al., 2011). CT River Valley - production rate using only the ${ }^{10}$ Be dataset from the Connecticut River Valley (Balco et al., 2009).

${ }^{10}$ Be production rates is $3.96 \pm 0.05$ atoms $\mathrm{g}^{-1} \mathrm{a}^{-1}(1 \sigma$ uncertainty of $1.3 \%)$, but we favour the error-weighted mean Baffin Bay reference ${ }^{10} \mathrm{Be}$ production rate of $3.96 \pm 0.07$ atoms $\mathrm{g}^{-1} \mathrm{a}^{-1}$ ( $1 \sigma$ uncertainty of $1.8 \%$; Table 2$)$ because it gives highest weight to the Marrait moraine dataset, which has the most precise ${ }^{14} \mathrm{C}$ control of the three calibration datasets, and its uncertainty is more conservative. We emphasize that site-specific and Baffin Bay production rate uncertainties reflect only (i) individual ${ }^{10} \mathrm{Be}$ measurement uncertainties, (ii) the scatter of ${ }^{10} \mathrm{Be}$ measurements at each site and (iii) the uncertainty in the independent radiocarbon control for each calibration dataset. However, we report these values because they are directly comparable to the reported production rates and their stated uncertainties at other ${ }^{10}$ Be calibration sites (Tables 2 and 3). Next, we briefly review additional Northern Hemisphere ${ }^{10} \mathrm{Be}$ calibration sites and their reported production rates. These calibration sites are then used to assess the combined analytical and scaling uncertainty in an Arctic production rate.

\section{Oledalen and Halsnøy calibration sites, Norway}

The production rate from the Oldedalen rock avalanche site is $4.04 \pm 0.13$ atoms $\mathrm{g}^{-1} \mathrm{a}^{-1}\left(n=7^{10} \mathrm{Be}\right.$ measurements; $3.2 \%$ uncertainty). The independent age control is a single ${ }^{14} \mathrm{C}$ age of $6010 \pm 110 \mathrm{cal}$ a BP from wood entrained in the avalanche deposit (Nesje, 2002; Goehring et al., 2012).

At Halsnøy, the production rate is $4.19 \pm 0.11$ atoms $\mathrm{g}^{-1}$ $\mathrm{a}^{-1}$ ( $n=8{ }^{10}$ Be measurements; $2.6 \%$ uncertainty). This value is slightly lower than the value reported in Goehring et al. (2012) because we have removed the uplift component to make this production rate directly comparable with the Baffin Bay datasets (see discussion below). The Halsnøy site

Table 3a. Arctic ${ }^{10}$ Be production-rate calibration datasets, including an altitude uplift correction.

\begin{tabular}{|c|c|c|c|c|c|c|}
\hline Scaling scheme ID & Baffin Bay & Norway-Oldedalen & Norway-Halsnøy & Norway-Grøtlandsura & Norway-Russenes & Arctic \\
\hline St & $4.16 \pm 0.07(1.8 \%)$ & $4.04 \pm 0.13(3.2 \%)$ & $4.25 \pm 0.11(2.6 \%)$ & $3.73 \pm 0.15(4.0 \%)$ & $4.14 \pm 0.21(5.1 \%)$ & $4.16 \pm 0.19(4.5 \%)$ \\
\hline De & $4.31 \pm 0.07(1.7 \%)$ & $4.17 \pm 0.13(3.1 \%)$ & $4.35 \pm 0.11(2.5 \%)$ & $3.81 \pm 0.15(3.9 \%)$ & $4.25 \pm 0.21(4.9 \%)$ & $4.31 \pm 0.20(4.6 \%)$ \\
\hline $\mathrm{Du}$ & $4.27 \pm 0.07(1.7 \%)$ & $4.16 \pm 0.13(3.1 \%)$ & $4.35 \pm 0.11(2.5 \%)$ & $3.78 \pm 0.15(4.0 \%)$ & $4.22 \pm 0.21(5.0 \%)$ & $4.27 \pm 0.21(4.9 \%)$ \\
\hline $\mathrm{Li}$ & $4.58 \pm 0.08(1.8 \%)$ & $4.44 \pm 0.14(3.2 \%)$ & $4.65 \pm 0.12(2.6 \%)$ & $4.08 \pm 0.16(3.9 \%)$ & $4.54 \pm 0.23(5.1 \%)$ & $4.58 \pm 0.23(5.0 \%)$ \\
\hline $\mathrm{Lm}$ & $4.16 \pm 0.07(1.8 \%)$ & $4.04 \pm 0.13(3.2 \%)$ & $4.25 \pm 0.11(2.6 \%)$ & $3.73 \pm 0.15(4.0 \%)$ & $4.14 \pm 0.21(5.1 \%)$ & $4.16 \pm 0.19(4.5 \%)$ \\
\hline
\end{tabular}

Table 3b. Comparison of ${ }^{10}$ Be production-rate calibration datasets.

\begin{tabular}{|c|c|c|c|c|c|}
\hline Scaling & Arctic & NENA & New Zealand & Patagonia & Global (pre-2008) \\
\hline St & $3.96 \pm 0.15(3.7 \%)$ & $3.91 \pm 0.19(4.9 \%)$ & $3.88 \pm 0.10(2.5 \%)$ & $\mathrm{n} / \mathrm{a}$ & $4.47 \pm 0.40(8.9 \%)$ \\
\hline $\mathrm{Du}$ & $4.09 \pm 0.18(4.3 \%)$ & $4.13 \pm 0.20(4.8 \%)$ & $3.91 \pm 0.10(2.5 \%)$ & $3.95 \pm 0.12(3.0 \%)$ & $4.42 \pm 0.53(12.0 \%)$ \\
\hline $\mathrm{Li}$ & $4.38 \pm 0.19(4.3 \%)$ & $4.47 \pm 0.22(4.9 \%)$ & $4.22 \pm 0.11(2.6 \%)$ & $4.21 \pm 0.13(3.1 \%)$ & $4.85 \pm 0.49(10.1 \%)$ \\
\hline $\mathrm{Lm}$ & $3.96 \pm 0.15(3.7 \%)$ & $3.85 \pm 0.19(4.9 \%)$ & $3.79 \pm 0.10(2.6 \%)$ & $3.70 \pm 0.11(3.0 \%)$ & $4.37 \pm 0.39(8.9 \%)$ \\
\hline
\end{tabular}

Values in parentheses are $1 \sigma$ uncertainties. The Oldedalen values require no correction. NENA - north-eastern North America production rate; Balco et al. (2009). New Zealand-Putnam et al. (2010a). Patagonia-Kaplan et al. (2011). Global-Balco et al. (2008). For the New Zealand dataset we report the PNZ1 values, which were calculated with the same geomagnetic framework as the arctic values. 
comprises ${ }^{10} \mathrm{Be}$ measurements from moraine boulders and ${ }^{14} \mathrm{C}$-dated sediments deposited in a paleolake basin that rested below the local marine limit; these lake sediments are linked to the moraine (Goehring et al., 2012; Lohne et al., 2012). The independent ${ }^{14} \mathrm{C}$ control from the lake basin probably reflects the timing of moraine abandonment; however, the possibility that these sediments and related ${ }^{14} \mathrm{C}$ control date the metamorphosis from a marine to freshwater environment cannot be ruled out entirely (Lohne et al., 2012). In the former scenario, the numerous ${ }^{14} \mathrm{C}$ ages and high-precision ${ }^{10} \mathrm{Be}$ measurements from the Halsnøy site would yield an exceptionally well-constrained production rate of $4.19 \pm 0.11$ atoms $\mathrm{g}^{-1} \mathrm{a}^{-1}$. In their original publication, the reference ${ }^{10} \mathrm{Be}$ production rates from Oldedalen and Halsnøy were averaged to generate one reference ${ }^{10} \mathrm{Be}$ production rate (Goehring et al., 2012); re-calculated with our methods, that value is $4.12 \pm 0.11$ atoms $\mathrm{g}^{-1} \mathrm{a}^{-1}$.

\section{Grøtlandsura and Russenes calibration sites, Norway}

The production rates at the Grøtlandsura and Russenes avalanche sites are $3.63 \pm 0.15\left(n=3{ }^{10} \mathrm{Be}\right.$ measurements; $4.1 \%$ uncertainty) and $4.03 \pm 0.21$ atoms $\mathrm{g}^{-1} \mathrm{a}^{-1}\left(n=3{ }^{10} \mathrm{Be}\right.$ measurements; $5.0 \%$ uncertainty), respectively. Again, these values are slightly different from those in the original publication because we have recast the production rates using the same scaling and air pressure implementations that were used for the Baffin Bay, Halsnøy and Oledalen datasets. For the Grotlandsura and Russenes calibration sites, the original authors presented an error-weighted production rate of $3.96 \pm 0.16$ atoms $\mathrm{g}^{-1} \mathrm{a}^{-1}$ (Fenton et al., 2011); here, the re-calculated value is $3.89 \pm 0.16$ atoms $\mathrm{g}^{-1} \mathrm{a}^{-1}$, which incorporates shielding uncertainties of $\sim 12-22 \%$ due to snow and moss cover on sampled boulders.

The Grøtlandsura avalanche is constrained by two minimum-limiting ${ }^{14} \mathrm{C}$ ages from marine mollusks collected from interstitial cavities at the base of the avalanche deposit. The calibrated ${ }^{14} \mathrm{C}$ ages range from 11000 to $11500 \mathrm{cal}$ a BP and yield a weighted mean of $11424 \pm 108$ cal a BP (Fenton et al., 2011). The age of the Russenes avalanche is constrained by three ${ }^{14} \mathrm{C}$ ages from marine mollusks that yield a weighted mean of $10942 \pm 77 \mathrm{cal}$ a BP. The maximum age of both avalanches is constrained by stratigraphically older moraines that are assigned ages of $\sim 11530$ a BP (Fenton et al., 2011)

\section{Connecticut River Valley, New England, USA}

The Connecticut River Valley calibration site comprises four independent locations that were originally included in the broader NENA production-rate dataset (Balco et al., 2009). We include these sites in our analysis because the geomagnetic cutoff rigidity and sample elevations at these locations are similar to those of the Baffin Bay and Norwegian calibration sites. The production rate for the entire dataset is $3.98 \pm 0.13$ atoms $\mathrm{g}^{-1} \mathrm{a}^{-1}\left(n=8{ }^{10} \mathrm{Be}\right.$ measurements; $3.2 \%$ uncertainty), and at each of the calibration sites, the independent age of the geomorphic feature is linked directly to the well-constrained New England varve chronology (see Balco et al., 2009; Ridge et al., 2012).

\section{A ${ }^{10} \mathrm{Be}$ production-rate calibration for the Arctic}

The Baffin Bay ${ }^{10}$ Be production rate presented above overlaps with all individual ${ }^{10} \mathrm{Be}$ production rates from Norway at $2 \sigma$ (Table 2), and overlaps the Oldedalen, Russenes and Con- necticut River Valley values at $1 \sigma$ uncertainty. To calculate an Arctic production rate with an uncertainty that incorporates potential scaling errors, we use the reference Baffin Bay production rate as determined by the misfit between predicted ${ }^{10} \mathrm{Be}$ ages and true ages to calculate ${ }^{10} \mathrm{Be}$ ages at the aforementioned calibration sites. Again, the baseline production rate determined using this method (3.96 atoms $\mathrm{g}^{-1} \mathrm{a}^{-1}$; St) matches the error-weighted mean of the Baffin Bay sitespecific production rates described above.

The relative scatter of predicted ages compared with the true age for the entire dataset yields a standard deviation of $5.2 \%$ (Table S2; Fig. 5). The standard deviation of the sitespecific averages is $4.3 \%$ and the mean of these intrasite deviations is $3.7 \%$; this value is an estimate of the scatter at a particular site attributed to measurement and geologic uncertainties. The amount by which the standard deviation of the entire dataset $(5.2 \%)$ exceeds the mean of the intrasite distributions $(3.7 \%)$ is an estimate of the intersite scatter attributed to scaling uncertainties. The production rate uncertainty can be estimated by solving the standard error propagation equation, resulting in a total uncertainty of $3.7 \%$, and thus we calculate an Arctic reference production rate of 3.96 \pm 0.15 atoms $\mathrm{g}^{-1} \mathrm{a}^{-1}(\mathrm{St})$. In comparison, this same methodology results in a slightly higher uncertainty of $4.3 \%$ for the Li scaling scheme (Table S2; Fig. 5).

\section{Glacioisostatic uplift and air-pressure distribution}

All the discussed calibration sites rest near current or paleo ice sheets and are affected by fluctuating air-pressure distributions, which can affect the production of ${ }^{10} \mathrm{Be}$. Specifically, air pressure at these calibration sites is governed by (i) changing sample altitude driven by glacioisostatic uplift, (ii) ice-sheet-related pressure anomalies and (iii) eustatic sea level. Of these three factors controlling air pressure and thus the production of ${ }^{10} \mathrm{Be}$, the effect of glacioisostatic uplift on ${ }^{10} \mathrm{Be}$ production can be most readily quantified using the standard altitude-pressure relationship. Our calibration sites initially rested at lower altitudes and because the timeintegrated altitude of each of our calibration sites rested deeper in the atmosphere, they experienced lower production rates, which might cause us to underestimate production rates.

To quantify the effect of increasing altitude during sample exposure on our production rates, we utilized well-constrained regional emergence curves from western Greenland and Clyde Inlet (Fig. S1; Long et al., 2006; Briner et al., 2007) and allowed ${ }^{10} \mathrm{Be}$ production to vary due to temporally changing altitude. By applying this uplift correction to our Baffin Bay calibration sites, which experienced between $\sim 45$ and $60 \mathrm{~m}$ of uplift, the production rate increases by $4.8 \%$ (Fig. S1; Table 3). By comparison, at the Halsnøy site in southern Norway where samples experienced $\sim 70 \mathrm{~m}$ of uplift, the production rate increases by $1.4 \%$ (Goehring et al., 2012). Although these two sites experienced comparable amounts of total uplift, the corrections for the Baffin Bay sites are greater because their rate of uplift occurred more slowly.

Correcting production rates solely for the uplift-driven altitude effect would result in a maximum production rate because the altitude effect is counteracted to an unknown degree by (i) ice-sheet-driven changes to air pressure (Stone, 2000; Staiger et al., 2007) and (ii) eustatic sea-level changes. (i) Katabatic wind effects at ice-sheet margins would result in lower atmospheric pressure at sample sites leading to higher production rates. For sites near ice sheets exposed since the Last Glacial Maximum, this effect could have been 


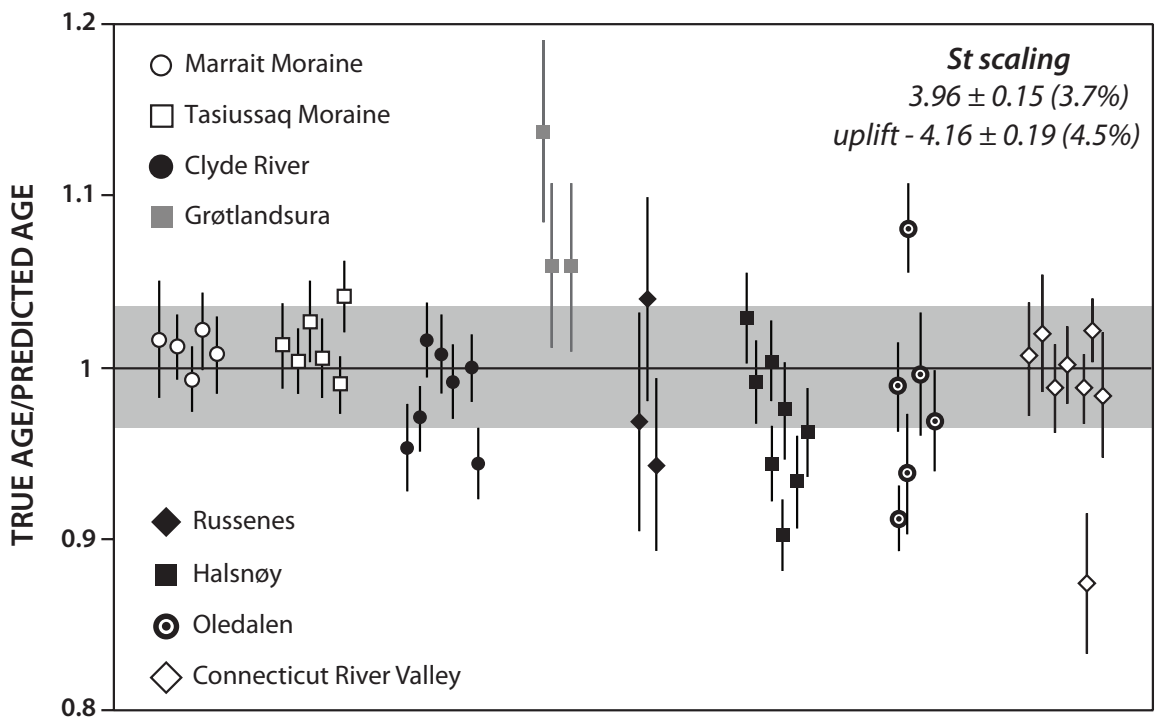

Figure 5. Fit of the St and Li scaling schemes to the Arctic calibration dataset. A value of 1 represents a perfect fit between predicted ${ }^{10} \mathrm{Be}$ ages and the true age at each site. Values $>1$ indicate that a lower production is needed to achieve a perfect fit between predicted and true ages; values $<1$ require a higher production rate. Only the misfit plots using the base (no-uplift) production rates are shown; however, we show the uplift-corrected production rates that are calculated using this same method. The misfits between the predicted and true ages at each site are similar regardless of which production rate is used (base vs. uplift-corrected), and therefore the misfit plots using the uplift-corrected production rate look nearly identical to those shown here. See Table S2 for details.

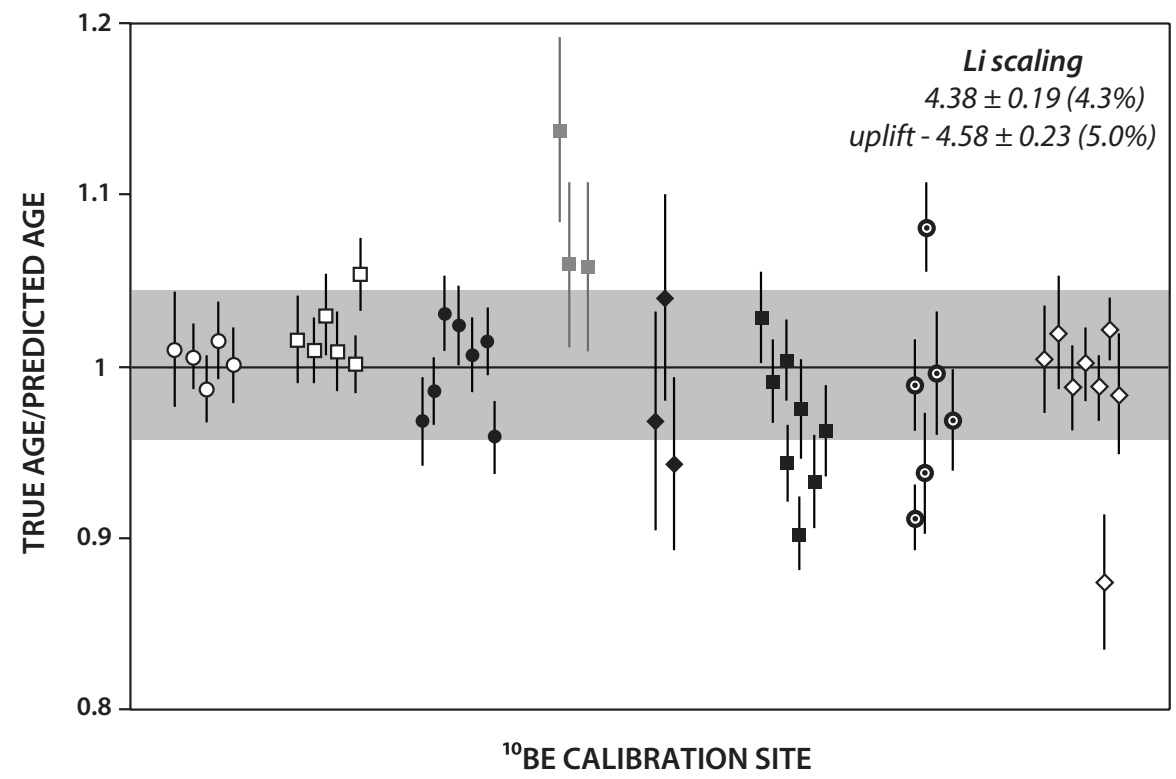

$\sim 10 \%$, although the effect is short-lived (Staiger et al., 2007) and should also be considered a maximum correction as our discussed calibration sites are Holocene in age. (ii) Eustatic sea level during emplacement of the Baffin Bay ${ }^{10}$ Be calibration features ( 9200-8000 a) was $\sim 25-10 \mathrm{~m}$ below present (i.e. Bard et al., 1996), which would also counteract the uplift-based altitude effect - lower eustatic sea level would result in lower site-specific atmospheric pressure (i.e. higher ${ }^{10}$ Be production).

Nonetheless, we tested the uplift-corrected Baffin Bay production rate (Tables 3 and S2) by calculating predicted ${ }^{10} \mathrm{Be}$ ages at all the Baffin Bay, Norwegian and Connecticut River Valley calibration sites and comparing these predicted ages with the true age of each site's geomorphic feature (Table S2). Critical to this approach, however, is that predicted ${ }^{10} \mathrm{Be}$ ages at each site must be calculated in the same manner as the uplifted-corrected production rates using locally calibrated uplift curves and an altitude that varies temporally. We relied on locally calibrated uplift curves at each of the calibration sites to calculate predicted ${ }^{10} \mathrm{Be}$ ages with the exception of the Oledalen and Connecticut River Valley sites. The Oledalen site is too young ( 6100 a BP) to have undergone any significant amount of post-glacial uplift, and for the Connecticut River Valley calibration site, we extracted paleoelevation histories from the ICE-5G glacioisostatic rebound model in lieu of a locally calibrated uplift curve (Peltier, 2004; Balco et al., 2009).

Using the uplift-corrected production rate, the relative scatter of predicted ages compared with the true age for the entire dataset yields a standard deviation of $6.2 \% \quad(\mathrm{St}$; Table S2; Fig. 5), which is similar to but slightly higher than the relative scatter of true age/predicted age ratios using the base (no-uplift) production rate $(5.2 \%$; Table S2). The total inter-site scatter due to potential scaling uncertainties, which is an estimate of the total production-rate uncertainty, is $4.5 \%$, which again is slightly higher than that for the no-uplift production rate $(3.7 \%$; Fig. 5$)$. For the Li scaling scheme, the uplift-corrected production rate's total estimated uncertainty is $5.0 \%$ (Table S2; Fig. 5).

For the Arctic calibration dataset, ${ }^{10} \mathrm{Be}$ ages at each site calculated using the base and uplift-corrected production rates are almost identical despite the fact that the upliftcorrected production rates are $\sim 4.0-4.5 \%$ higher. This similarity arises from all the calibration sites having relatively comparable uplift histories, and the process of calculating uplift-corrected ${ }^{10} \mathrm{Be}$ ages in the exact same manner as calculating the uplift-corrected production rate; sample altitude and thus ${ }^{10} \mathrm{Be}$ production must be allowed to vary 
Table 4. Ratios of ${ }^{10}$ Be production rates compared with each other based on the St and Li scaling schemes.

\begin{tabular}{|c|c|c|c|c|}
\hline & Arctic & NENA & New Zealand & Global \\
\hline \multicolumn{5}{|l|}{ St (Lal/Stone) } \\
\hline Arctic & - & $0.99 \pm 0.05$ & $0.98 \pm 0.03$ & $1.13 \pm 0.10$ \\
\hline NENA & $1.01 \pm 0.04$ & - & $0.99 \pm 0.03$ & $1.14 \pm 0.11$ \\
\hline New Zealand & $1.02 \pm 0.04$ & $1.01 \pm 0.05$ & - & $1.15 \pm 0.11$ \\
\hline Global & $0.89 \pm 0.04$ & $0.87 \pm 0.05$ & $0.87 \pm 0.02$ & - \\
\hline \multicolumn{5}{|l|}{ Li (Lifton) } \\
\hline Arctic & - & $1.02 \pm 0.05$ & $0.96 \pm 0.03$ & $1.11 \pm 0.11$ \\
\hline NENA & $0.98 \pm 0.04$ & - & $0.94 \pm 0.03$ & $1.09 \pm 0.11$ \\
\hline New Zealand & $1.04 \pm 0.05$ & $1.06 \pm 0.05$ & - & $1.15 \pm 0.12$ \\
\hline Global & $0.90 \pm 0.04$ & $0.92 \pm 0.05$ & $0.87 \pm 0.02$ & - \\
\hline
\end{tabular}

For simplicity we only report ratios using the Li scaling scheme, which is representative of other scaling schemes that include variations in the magnetic field.

temporally. Using either the base or the uplift-corrected production rate results in almost identical ages at the Arctic calibration sites that have undergone uplift, but this will not be true at locations where the sample elevation has remained constant through its exposure history. In this case, using a production rate that is $4.0-4.5 \%$ higher will result in ${ }^{10} \mathrm{Be}$ ages that are $4.0-4.5 \%$ younger.

So, should the base or uplift-corrected production rate be used? We recommend using the Arctic production rate that does not include an uplift component because (i) this production rate results in a slightly better fit between predicted and true ages for the calibration dataset (Fig. 5; Table S2), and (ii) the Oledalen site, the only calibration site not to have experienced significant uplift, has a site-specific production rate of $4.04 \pm 0.13$ atoms $\mathrm{g}^{-1} \mathrm{a}^{-1}$, consistent with the base Arctic production rate of $3.96 \pm 0.15$ atoms $\mathrm{g}^{-1} \mathrm{a}^{-1}$ presented here. However, if the uplift-corrected production rate is chosen to calculate ${ }^{10} \mathrm{Be}$ ages, sample altitude and ${ }^{10} \mathrm{Be}$ production must be allowed to vary temporally; failing to implement this approach will result in ${ }^{10} \mathrm{Be}$ ages that are systematically too young. To fully test base vs. upliftcorrected production rates additional ${ }^{10} \mathrm{Be}$ calibrations are needed from altitude-stable locations.

\section{Where to use the Arctic production rate}

The calibration sites occupy a relatively narrow range of altitudes and geomagnetic cutoff rigidities, and therefore the accuracy of exposure ages calculated at similar locations is minimally influenced by differences in scaling assumptions between scaling schemes (Balco et al., 2009). Thus, because the effects of the magnetic field are small at relatively high latitudes where the calibration sites are located, the Arctic reference production rate should result in accurate exposure ages at other high-latitude $\left(>40^{\circ} \mathrm{N}\right)$, low-elevation $(<1000 \mathrm{~m}$ asl) sites. In addition, although the Baffin Bay and Norwegian calibration sites are Holocene in age, the Connecticut River Valley calibration sites are up to $\sim 16 \mathrm{ka}$ in age; the agreement between predicted and true ages at the Connecticut River Valley sites (Fig. 5) indicates that the Arctic production rate is applicable through at least the Lateglacial period.

We also note that when considered independently, the Baffin Bay calibration sites all have statistically identical production rates (Table 2). Even when these production rates are corrected for the effects of glacioisostatic uplift using local uplift records, the production rates remain statistically indistinguishable, suggesting that throughout their exposure histories the Baffin Bay calibration sites experienced similar air- pressure distributions. Accordingly, we recommend that the Baffin Bay production rate of $3.96 \pm 0.07$ atoms $\mathrm{g}^{-1} \mathrm{a}^{-1}$ (St; $1.8 \%$ uncertainty) be used for calculating exposure ages from low-elevation sites spanning the Holocene in the Baffin Bay region. Beyond the Baffin Bay region, we recommend using the Arctic production rate $\left(3.96 \pm 0.15\right.$ atoms $\mathrm{g}^{-1} \mathrm{a}^{-1}$; St) to calculate exposure ages, which propagates an uncertainty of $3.7 \%$ to account for SLHL scaling uncertainties.

We urge caution in using the Baffin Bay and Arctic production rates at lower latitudes and higher elevations; however, these production rates are, within errors, identical to the NENA ${ }^{10} \mathrm{Be}$ production rate of $3.91 \pm 0.19$ atoms $\mathrm{g}^{-1} \mathrm{a}^{-1}$ (Table 3; St; Balco et al., 2008). In addition, the Baffin Bay and Arctic ${ }^{10}$ Be production rates are consistent with recent regional ${ }^{10} \mathrm{Be}$ production-rate calibration datasets from New Zealand $\left(3.88 \pm 0.10\right.$ atoms $\mathrm{g}^{-1} \mathrm{a}^{-1}, \sim 1030 \mathrm{~m}$; Putnam et al., 2010a) that was subsequently confirmed in Patagonia (Kaplan et al., 2011; Tables 3 and 4). With St scaling, the Baffin Bay and Arctic production rates overlap with the New Zealand value at $1 \sigma$; however, the production rates diverge when using the remaining scaling schemes that account for fluctuations in the paleomagnetic field (Table 4). These differences may relate to uncertainties in correcting for paleomagnetic field variations or to the scaling of ${ }^{10} \mathrm{Be}$ production with elevation, or perhaps reflect real differences in the ${ }^{10}$ Be production rate between hemispheres.

\section{Conclusions}

${ }^{10} \mathrm{Be}$ measurements from well-dated glacial deposits on opposing sides of Baffin Bay at low elevations afford a Baffin Bay SLHL reference ${ }^{10} \mathrm{Be}$ production rate of $3.96 \pm 0.07$ atoms $\mathrm{g}^{-1} \mathrm{a}^{-1}$. Combined with ${ }^{10} \mathrm{Be}$ calibration sites from elsewhere in the Arctic, we suggest an Arctic-wide SLHL ${ }^{10} \mathrm{Be}$ production rate value of $3.96 \pm 0.15$ atoms $\mathrm{g}^{-1} \mathrm{a}^{-1}$. The Baffin Bay and Arctic-wide ${ }^{10} \mathrm{Be}$ production rates have $1 \sigma$ errors of $<2$ and $3.7 \%$, respectively, and in turn considerably reduce the systematic error contributed by production rate uncertainties to ${ }^{10} \mathrm{Be}$ exposure dating in this region. Furthermore, these calibration sites require minimal scaling to SLHL, reducing uncertainties in scaling model effects on production rate calculations. This progress is particularly important when comparing ${ }^{10} \mathrm{Be}$-based records of ice-margin change to welldated, high-resolution climate records. Even if minor uncertainties in ${ }^{10} \mathrm{Be}$ dating remain related to the influence of altitude, sea level and pressure-field reorganization as triggered by isostatic uplift and ice-sheet configuration, a robust ${ }^{10} \mathrm{Be}$ production rate for the Arctic is now in place. Future inter-comparisons between ${ }^{10}$ Be-based datasets 
(e.g. interhemispheric), and between ${ }^{10} \mathrm{Be}$ records and highresolution climate records, will be further improved by additional high-precision ${ }^{10} \mathrm{Be}$ production-rate calibration experiments.

\section{Supporting information}

Additional supporting information can be found in the online version of this article at the publisher's web-site.

Table S1. Pluto Lake ${ }^{14} \mathrm{C}$ sample information.

Table S2. Site-specific true age/predicted age misfit statistics.

Fig. S1. Emergence curves for the Marrait, Tasiussaq and Clyde River datasets used to calculate uplift-corrected production rates.

Please note: This supporting information is supplied by the authors, and may be re-organized for online delivery, but is not copy-edited or typeset by Wiley-Blackwell. Technical support issues arising from supporting information (other than missing files) should be addressed to the authors.

Acknowledgements. We thank Susan Zimmerman, Dylan Rood and Bob Finkel for careful ${ }^{10} \mathrm{Be}$ measurements at Lawrence Livermore National Laboratory, and Sam Kelley for assistance in the field. We thank Greg Balco and an anonymous reviewer for their constructive reviews that greatly improved this manuscript. Greg Balco deserves an additional mention for his insightful comments and suggestions during this manuscript's revision phase. This work was partially supported by the US National Science Foundation (NSF-BCS 0752848 and NSF-BCS 1002597). J. M. S. acknowledges the Comer Science and Educational Foundation, the Lamont Climate Center and NSF-EAR (03-45865). N. E. Y. acknowledges partial support from an LDEO post-doctoral fellowship. This is LDEO contribution 7684.

Abbreviations. NENA, north-eastern North America; SLHL, sea-level high-latitude.

\section{References}

Balco G. 2011. Contributions and unrealized potential contributions of cosmogenic-nuclide exposure dating to glacier chronology, 1990-2010. Quaternary Science Reviews 30: 3-27.

Balco G, Briner J, Finkel RC, et al. 2009. Regional beryllium-10 production rate calibration for late-glacial northeastern North America. Quaternary Geochronology 4: 93-107.

Balco G, Stone J, Lifton N, et al. 2008. A simple, internally consistent, and easily accessible means of calculating surface exposure ages and erosion rates from $\mathrm{Be}-10$ and $\mathrm{Al}-26$ measurements. Quaternary Geochronology 3: 174-195.

Bard E, Hamelin B, Arnold M, et al. 1996. Deglacial sea-level record from Tahiti corals and the timing of global meltwater discharge. Nature 382: 241-244.

Briner JP, Bini AC, Anderson RS. 2009. Rapid early Holocene retreat of a Laurentide outlet glacier through an Arctic fjord. Nature Geoscience 2: 496-499.

Briner JP, Overeem I, Miller GH, et al. 2007. The deglaciation of Clyde Inlet, northeastern Baffin Island, Arctic Canada. Journal of Quaternary Science 22: 223-232.

Briner JP, Stewart HAM, Young NE, et al. 2010. Using proglacialthreshold lakes to constrain fluctuations of the Jakobshavn Isbrae ice margin, western Greenland, during the Holocene. Quaternary Science Reviews 29: 3861-3874.

Briner JP, Young NE, Goehring BM, et al. 2012. Constraining Holocene 10Be production rates in Greenland. Journal of Quaternary Science 27: 2-6.

Corbett LB, Young NE, Bierman PR, et al. 2011. Paired bedrock and boulder $10 \mathrm{Be}$ concentrations resulting from early Holocene ice retreat near Jakobshavn Isfjord. Quaternary Science Reviews 30: 1739-1749.

Desilets D, Zreda M, Prabu T. 2006. Extended scaling factors for in situ cosmogenic nuclides: new measurements at low latitude. Earth and Planetary Sciences Letters 246: 265-276.

Dunai TJ. 2001. Influence of secular variation of the magnetic field on production rates of in situ produced cosmogenic nuclides. Earth and Planetary Sciences Letters 193: 197-212.

Farber D, Hancock G, Finkel R, et al. 2005. The age and extent of tropical alpine glaciation in the Cordillera Blanca, Peru. Journal of Quaternary Science 20: 759-776.

Fenton CR, Hermanns R, Blikra L, et al. 2011. Regional 10Be production rate calibration for the past 12 ka deduced from the radiocarbon-dated Grøtlandsura and Russenes rock avalanches at $69^{\circ} \mathrm{N}$, Norway. Quaternary Geochronology 6: 437-452.

Goehring BM, Lohne ØS, Mangerud J, et al. 2012. Late Glacial and Holocene beryllium-10 production rates for western Norway. Journal of Quaternary Science 27: 89-96.

Gosse J, Evenson EB, Klein J, et al. 1995. Precise cosmogenic 10Be measurements in western North America: support for a global Younger Dryas cooling event. Geology 23: 877-880.

Gosse J, Klein J. 1996. Production rate of in-situ cosmogenic 10Be in quartz at high altitude and mid latitude. Radiocarbon 38: 154155.

Gosse JC, Phillips FM. 2001. Terrestrial in situ cosmogenic nuclides: theory and application. Quaternary Science Reviews 20: 14751560.

Heisinger B, Lal D, Jull AJT, et al. 2002a. Production of selected cosmogenic radionuclides by muons: 2. Capture of negative muons. Earth and Planetary Sciences Letters 200: 357-369.

Heisinger B, Lal D, Jull AJT, et al. 2002b. Production of selected cosmogenic radionuclides by muons: 1. Fast muons. Earth and Planetary Sciences Letters 200: 345-355.

Ivy-Ochs S, Schlüchter C, Kubik PW, et al. 1999. Moraine exposure dates imply synchronous Younger Dryas glacier advances in the European Alps and in the southern Alps of New Zealand. Geografiska Annaler 81A: 313-323.

Kaplan MR, Strelin JA, Schaefer JM, et al. 2011. In-situ cosmogenic $10 \mathrm{Be}$ production rate at Lago Argentino, Patagonia: implications for late-glacial climate chronology. Earth and Planetary Sciences Letters 309: 21-32.

Kaplan MR, Wolfe AP, Miller GH. 2002. Holocene environmental variability in southern Greenland inferred from lake sediments. Quaternary Research 58: 149-159.

Kohl C, Nishiizumi K. 1992. Chemical isolation of quartz for measurement of in-situ-produced cosmogenic nuclides. Geochimica et Cosmochimica Acta 56: 3583-3587.

Kubik P, Ivy-Ochs S. 2004. A re-evaluation of the 0-10ka $10 \mathrm{Be}$ production rate for exposure dating obtained from the Köfels (Austria) landslide. Nuclear Instruments and Methods in Physics Research B 223-224: 618-622.

Kubik P, Ivy-Ochs S, Masarik J, et al. 1998. Be and Al production rates deduced from an instantaneous event within the dendrocalibration curve, the landslide of Köfels, Ötz Valley, Austria. Earth and Planetary Sciences Letters 161: 231-241.

Laabs BJC, Munroe JS, Best LC, et al. 2013. Timing of the last glaciation and subsequent deglaciation in the Ruby Mountains, Great Basin, USA. Earth and Planetary Sciences Letters 361: 16-25.

Lal D. 1991. Cosmic ray labeling of erosion surfaces: in situ nuclide production rates and erosion models. Earth and Planetary Sciences Letters 104: 424-439.

Larsen P. 1996. In-situ production rates of cosmogenic 10Be and $26 \mathrm{Al}$ over the past 21,500 years determined from the terminal moraine of the Laurentide Ice Sheet, north-central New Jersey. MS thesis, University of Vermont.

Licciardi JM, Schaefer JM, Taggart JR, et al. 2009. Holocene glacier fluctuations in the Peruvian Andes indicate northern climate linkages. Science 325: 1677-1679.

Lifton N, Smart DF, Shea MA. 2008. Scaling time-integrated in situ cosmogenic nuclide production rates using a continuous geomagnetic model. Earth and Planetary Sciences Letters 268: 190-201.

Lifton NA, Bieber JW, Clem JM, et al. 2005. Addressing solar modulation and long-term uncertainties in scaling secondary 
cosmic rays for in situ cosmogenic nuclide applications. Earth and Planetary Sciences Letters 239: 140-161.

Lloyd JM, Park L, Kuijpers A, et al. 2005. Early Holocene palaeoceanography and deglacial chronology of Disko Bugt, West Greenland. Quaternary Science Reviews 24: 1741-1755.

Lohne O, Mangerud J, Svendsen JI. 2012. Timing of the Younger Dryas glacial maximum in western Norway. Journal of Quaternary Science 27: 81-88.

Long AJ, Roberts DH, Dawson S. 2006. Early Holocene history of the west Greenland Ice Sheet and the GH-8.2 event. Quaternary Science Reviews 25: 904-922.

Nesje A. 2002. A large rockfall avalanche in Oldedalen, inner Nordfjord, western Norway, dated by means of a sub-avalanche Salix sp.tree trunk. Norsk Geologisk Tidsskrift 82: 59-62.

Nishiizumi K. 2002. 10Be, 26Al, 36Cl, and 41Ca AMS standards: abstract O16-1. In: 9th Conference on Accelerator Mass Spectrometry (September 9-13, 2002, Nagoya, Japan), p. 130.

Nishiizumi K, Finkel R, Klein J, et al. 1996. Cosmogenic production of ${ }^{7} \mathrm{Be}$ and ${ }^{10} \mathrm{Be}$ in water targets. Journal of Geophysical Research 101: $22,225-22,232$.

Nishiizumi K, Imamura M, Caffee M, et al. 2007. Absolute calibration of ${ }^{10} \mathrm{Be}$ AMS standards. Nuclear Instruments and Methods in Physics Research B 258: 403-413.

Nishiizumi K, Winterer E, Kohl C, et al. 1989. Cosmic ray production rates of ${ }^{26} \mathrm{Al}$ and ${ }^{10} \mathrm{Be}$ in quartz from glacially polished rocks. Journal of Geophysical Research 94: 17907-17915.

Peltier W. 2004. Global glacial isostasy and the surface of the ice-age Earth: the ICE-5G model and GRACE. Annual Review of Earth and Planetary Sciences 32: 111-149.

Putnam A, Schaefer J, Barrell DJA, et al. 2010a. In situ cosmogenic $10 \mathrm{Be}$ production-rate calibration from the Southern Alps, New Zealand. Quaternary Geochronology 5: 392-409.

Putnam AE, Denton GH, Schaefer JM, et al. 2010b. Glacier advance in southern middle-latitudes during the Antarctic Cold Reversal. Nature Geoscience 3: 700-704.

Putnam A, Schaefer JM, Denton GH, et al. 2012. Regional climate control of glaciers in New Zealand and Europe during the preindustrial Holocene. Nature Geoscience 5: 627-630.

Ridge JC, Balco G, Bayless RL, et al. 2012. The new North American varve chronology: A precise record of southeastern Laurentide Ice
Sheet deglaciation and climate, 18.2-12.5 kyr BP, and correlations with Greenland ice core records. American Journal of Science 312: 685-722.

Rood DH, Hall S, Guilderson TP, et al. 2010. Challenges and opportunities in high precision Be-10 measurements at CAMS. Nuclear Instruments and Methods in Physics Research B 268: 730732.

Schaefer JM, Denton GD, Kaplan MR, et al. 2009. High-frequency Holocene glacier fluctuations in New Zealand differ from the northern signature. Science 324: 622-625.

Staiger J, Gosse J, Toracinta R, et al. 2007. Atmospheric scaling of cosmogenic nuclide production: climate effect. Journal of Geophysical Research 112: B02205.

Stone JO. 2000. Air pressure and cosmogenic isotope production. Journal of Geophysical Research 105: 23,753-23,759.

Stone JO, Balco GA, Sugden DE, et al. 2003. Holocene deglaciation of Marie Byrd Land, West Antarctica. Science 299: 99-102.

Stone JO, Ballantyne CK, Fifield K. 1998. Exposure dating and validation of periglacial weathering limits, northwest Scotland. Geology 26: 587-590.

Weidick A. 1968. Observations on some Holocene glacier fluctuations in West Greenland. Meddelelser om Grønland 165: 202.

Weidick A, Bennike O. 2007. Quaternary glaciation history and glaciology of Jakobshavn Isbræ and the Disko Bugt region, West Greenland: a review. Geological Survey of Denmark and Greenland Bulletin 14: 1-71.

Young NE, Briner JP, Axford Y, et al. 2011b. Response of a marineterminating Greenland outlet glacier to abrupt cooling 8200 and 9300 years ago. Geophysical Research Letters 38: L24701.

Young NE, Briner JP, Rood DH, et al. 2012. Glacier extent during the Younger Dryas and 8.2-ka event on Baffin Island, Arctic Canada. Science 337: 1330-1333.

Young NE, Briner JP, Rood DH, et al. 2013. Age of the Fjord Stade moraines in the Disko Bugt region, western Greenland, and the 9.3 and 8.2 ka cooling events. Quaternary Science Reviews 60: 76-90.

Young NE, Briner JP, Stewart HAM, et al. 2011a. Response of Jakobshavn Isbrae, Greenland, to Holocene climate change. Geology 39: 131-134. 